\title{
Teachers' Self-concept and Valuing of Learning: Relations with Teaching Approaches and Beliefs about Students
}

\author{
Alexander Seeshing Yeung \\ Rhonda G. Craven \\ Gurvinder Kaur
}

\section{Author Note}

The research was funded by the Australian Research Council.

\begin{abstract}
One’s self-concept and value perceptions can significantly influence one’s behaviors and beliefs. Australian teachers from urban and rural areas of the state of New South Wales were asked to respond to survey items on two predictors (teacher self-concept, valuing of learning) and 3 outcomes (2 immediate: student-centered and teacher-centered teaching; 1 long-term: beliefs in ability constraints). Confirmatory factor analysis established the five latent factors. Structural equation modeling found significant paths from teacher self-concept to both student-centered and teacher-centered approaches but not beliefs about student ability. The positive path from valuing of learning to student-centered teaching was statistically significant but the path to teacher-centered teaching was not. The significant path from valuing of learning to beliefs about student ability was negative indicating that teachers who value student learning were less likely to believe in ability constraints. The significant influences of teacher self-concept and valuing of learning on short-term and long-term outcomes have significant implications for teacher education. Teacher preparation programs should enhance self-concept together with teaching skills and facilitate an advocacy for students' learning rather than the teacher's teaching.
\end{abstract}

Keywords: Teachers, Self-concept, Valuing of Learning, Teaching Approaches, Beliefs about Students.

\section{Introduction}

Recent research on self-beliefs and perceived values has indicated that these constructs play an important role in affecting individual's behavior and performance (e.g., Author, 2012; Wang, 2000). For teachers, their self-beliefs about teaching and their valuing of learning are likely to influence the way they teach and the way they perceive their students' learning abilities.

Research to date has examined the relations between teacher self-beliefs and their values (Schwartz \& Bilsky, 1987), but a paucity of research has investigated how these teacher constructs may affect teaching and perceptions about students. This lack of knowledge has led us to research into the broader issue of the relations between teacher constructs as predictors predicting teaching approaches and beliefs. Specifically, this paper attempts to understand how 
teacher self-concept (i.e., competence beliefs) and valuing of learning differentially influence teaching approaches (student-centered vs. teacher centered) and perceptions about student abilities.

\section{Self-concept and Valuing of Learning as Predictors}

In academic self-concept research, self-concept is known to be a significant predictor of behavior and performance (Author, 1997; Author, 1999). Academic performance and selfconcept are often found to have mutually reinforcing effects on each other (Author, 2008). These reciprocal effects are known to be domain specific, and therefore in the context of teacher self-perceptions, teacher self-concept is likely to influence behaviors and beliefs related to teaching practices. From the perspective of expectancy-value theory (Wigfield \& Eccles, 2000), a teacher's valuing of learning together with a positive competence belief may contribute significantly to actual teaching behaviors and teaching-related beliefs. However, whereas few studies have examined the relation between teacher self-concept and values (e.g., Schwartz \& Bilsky, 1987), even less is known about their respective relations with teaching behaviors.

Self-concept. Teacher self-concept can be broadly defined as teachers’ self-perceptions of their own teaching effectiveness. Researchers have emphasized the importance of teachers' competence beliefs (often labeled as self-efficacy or self-concept), which may influence teacher-related psychological variables (Devos, Dupriez, \& Paquay, 2012, Klassen \& Chiu, 2010; Lee \& Tsai, 2010; Roche \& Marsh, 2000). Clearly it is important for teacher education programs to ensure preservice teachers develop positive teaching self-concepts, not only as a major goal in itself, but also as an important mediating factor that can have a positive impact on other desirable outcomes in teaching contexts (Roche \& Marsh, 2000). It is therefore important for teacher education to include self-concept enhancement elements to bring about 
sustainable benefits from programs that prepare teachers to teach effectively. However, the relation of teacher self-concept to other constructs is yet to be thoroughly understood.

Teachers’ perceptions of themselves and of their teaching can affect their actual classroom pedagogy. Their teaching is further regulated by these perceptions of teaching that develop as the interplay between perceptions and teaching practices continues (Gow \& Kember, 1993; Trigwell, Prosser, \& Waterhouse, 1999). It is therefore generally recognized that teachers’ genuine professional development has to begin with a change in their perceptions and beliefs related to teaching and learning (Gow \& Kember, 1993; Ho, Watkins, \& Kelly, 2001). In this paper, we use the term 'self-concept' to denote a general selfperception of teaching competence, as opposed to more specific terms often used to differentiate between teacher efficacy in terms of classroom management, instruction, etc. (Tschannen-Moran \& Woolfolk Hoy, 2001).

Valuing of learning. Values can be defined as a person's principles or standards of behavior. Our values influence many aspects of our lives, affecting both the way we construe and evaluate situations and the actions that we take in pursuit of important goals. Values involve general beliefs about desirable and undesirable ways of behaving in everyday life and about desirable and undesirable goals or end-states (Corey, Corey, \& Callahan, 2003). Hofstede (1980) defines values as “a broad tendency to prefer certain states of affairs over others” (p. 19). Teachers' values are known to influence students' values and their academic behavior and achievement. For example, Loughran (2006) emphasizes that "a teacher's norms and values and the extent to which they are enacted in practice, influence the manner in which students might develop their own” (p. 2). As personal and professional values are integral to teaching practice, a teacher's preference for one perspective to another perspective (Hofstede, 1980) could significantly influence their practice in the classroom. During teaching, teachers' values not only affect teachers' thinking and decisions, but also translate to teaching behavior 
and effectiveness (Huang, 2006). From a teacher's point of view, preferences may be made between an emphasis on teaching or on learning. In recent years, the valuing of learning has attracted attention over teaching (Mayer, 2009). Consistent with the constructivists' view that emphasizes the learners’ active cognitive processing during learning activities (Marshall, 1998), this emphasis on learning is becoming increasingly popular. In the classroom, if teachers demonstrate positive attitudes toward learning processes leading to learner outcomes, they are more likely to engage students in learning activities and deep learning processes-hence a student-centered approach. If teachers focus more on teaching procedures than learning processes, which may be time-consuming and less cost-effective (Author, 2012), then teaching is more likely to be teacher-centered. However, because values and competence beliefs are often highly related (Öztaş \& Dilmac, 2009), it is unclear how teachers' valuing of learning and sense of competence in teaching may affect their choice of teaching approaches.

\section{Teaching Approaches and Beliefs about Students}

From the above, we may anticipate that teachers' self-concept and valuing of learning may have different influences on a range of variables. However, how teacher self-concept and value impact on teaching approaches and teacher beliefs about student ability is primarily unknown. Here, we examine teaching approaches from a dichotomous perspective (student-centered vs. teacher-centered), and beliefs as teachers' perceptions of student ability from a more traditional, and often biological, viewpoint.

Beliefs. Beliefs shape behavior and help guide people in their general thinking process and in their decision-making (Wang, 2000). This is true for beliefs about the self (Author, 1997), and also true for beliefs about others. Understanding one’s beliefs help discover the core of one’s thinking and by understanding teachers' beliefs, one can explain their teaching processes and performance (Chen, Chang, Yang, \& Cheng, 2006). For some teachers, there may be a belief about student ability that is based heavily on a biological perspective (Hsiao \& 
Yang, 2010). That is, students who have continued to do well academically are expected to achieve because of their innate ability. Conversely, those who have continually found difficulties in learning are likely to remain weak academically. This diversity of beliefs is consistent with the works of Dweck and her associates (Dweck, Chiu, \& Hong, 1995; Erdley \& Dweck, 1993) identifying two implicit theories of personality—-the entity theory assuming that an individual's personal attributes are fixed vs. the incremental theory assuming that personal attributes are malleable. Research shows that people holding an entity (i.e., fixed) belief of ability are more oriented toward diagnosing other people's stable traits whereas those holding an incremental (i.e., malleable) theory tend to be more open to information about change over time (Heslin, Latham, \& Vande Walle, 2005).

As beliefs play an important role of guiding teachers to think, solve problems, and apply teaching techniques strategically (Lim \& Torr, 2007; Sang, Valcke, van Braak, \& Tondeur, 2009; Stuart \& Thurlow, 2000), beliefs about students’ ability constraints can have a longterm impact on teachers' ongoing classroom practices. As such, beliefs can be an outcome of long-term significance for teachers' ongoing career development, and can be an important indicator of their professionalism (Zeng, 2008). Among other factors that may influence teaching-related beliefs, Chen and Chang (2004) emphasize the significance of the self factor, and the value the teachers hold, impacting on beliefs and teaching processes.

In terms of teaching processes, research has shown that students responding to teachers' comfort-oriented feedback not only perceive the teacher's entity (fixed) beliefs and low expectations, but also report lower motivation and self-expectations for their own performance. This implies that teachers' entity beliefs manifested in teaching processes may continually reinforce students' perceived limited capacity, leading to a sustained barrier to academic success. For example, even though comforting statements may be well intended to minimize detrimental effects of failure, comforting statements upon failure may result in 
students' self-beliefs of the stability of their low ability, which may further de-motivate and relegate them to even lower achievement (Rattan, Good, \& Dweck, 2012). One purpose of the present study was to empirically test the relations of an entity perspective with teachers' selfconcept, value, and teaching approaches.

Student-centered and teacher-centered approaches. Teaching approaches can be described in many ways (Author, 2012). Considering a spectrum from “transmissionism” (i.e., teacher-centered) to “connectionism” (i.e., student-centered) (Swan, 2007), we focused on these approaches as contrasting pedagogical practices. Student-centered pedagogy (Hattie, 2008) has received increasing attention. In this teaching approach, teachers allow students to construct knowledge by themselves and through social interactions (Doolittle \& Camp, 1999). A number of studies have shown that innovative, student-centered learning is effective for encouraging deep learning and academic engagement (Cannon \& Newble, 2000; Honkimaki, Tynjala, \& Valkonen, 2004). Supporting the constructivist view (Marshall, 1998), the studentcentered approach has the potential to engage a more academically diverse student body than the more conventional teacher-centered approach (Biggs, 2003).

In contrast, the teacher-centered approach places the teacher at the centre of the learning environment, transmitting information in the form of isolated facts and skills to students, who often assume a relatively passive role that is dependent upon the teacher's actions and knowledge. This is in direct contrast to the learner-centered approach, which focuses on students' learning needs, the development of conceptual understandings via active learning, and assumes that students play a proactive role and self-direct their own learning (Åkerlind, 2007; Ramsden, 1992; Trigwell et al., 1999). Teachers who adopt a teachercentered approach directly instruct students through lecturing, modeling, instructing, illustrating, demonstrating and coaching, and provide little chance for class participation (Castling, 1996). 
Although the names of the two approaches do not imply a dichotomy (Cuban, 1983), they are often accepted as such. Indeed, as teachers begin to understand new teaching and learning approaches, they may conceptualize the emerging continuum on the basis of these two approaches as the extremes of that continuum. For example, Saunders and Goldenberg (1996) describe the process by which four teachers moved from more traditional paradigms of teaching to more contemporary paradigms. Initially, these teachers drew on their implicit understandings of direct teaching (i.e., traditional, teacher-centered) to understand alternative instructional strategies. As their understanding progressed, they became more explicit in defining types of instruction and finding value in both traditional and alternative instruction. In fact, in real teaching situations, principles of a student-centered perspective can be embedded within a teacher-centered environment, and vice versa (Schuh, 2012). As Yeung, Taylor, and McWilliam (2012) have shown, even from the students' viewpoint, these two approaches are positively correlated $(r=.64)$, and therefore may not be treated as mutually exclusive.

Despite increasing advocates for the student-centered approach and evidence generally in favor of this approach, there is also growing evidence that student-centered learning may not work for around 30\% of the student population (Honkimaki et al., 2004). Without doubt, each of the many different existing approaches to teaching and learning may have their advantages and disadvantages. Teachers have to be aware of the ends they are heading toward so as to choose the right means. The many different approaches to teaching should not be regarded as mutually exclusive, and in reality, teachers are likely to use both student-centered and teacher-centered approaches together with a range of other approaches depending on the situation (Author, 2012). After all, the practice of teaching is mostly eclectic.

\section{The Present Investigation}

In the present study, we surveyed a sample of primary school teachers in Australia and examined their self-concept as a teacher and their valuing of learning as predictors of their 
beliefs about student ability and their teaching approaches. Hence there were two predictors (self-concept and valuing of learning) and three outcome variables (beliefs about student ability — an outcome that would have long-term consequences, and teaching approachesstudent-centered and teacher-centered approach which may be adopted immediately in the short term). We attempted to answer the research question: What is the relative strength of each of the two predictors in predicting teacher beliefs and teaching approaches? Based on previous empirical findings, two hypotheses were proposed:

Hypothesis 1: Teacher self-concept would be strong in predicting both teaching approaches (student-centered and teacher-centered).

Hypothesis 2: Holding a higher value for learning would predict the use of a studentcentered approach rather than a teacher-centered approach.

Hypothesis 3: Higher value for learning would also lead to lower beliefs of student ability as a stable and nonmalleable construct.

\section{Method}

\section{Participants}

Teachers from 52 primary schools in New South Wales, Australia participated in this study ( $N=208)$. These included 163 female and 45 male teachers. The qualifications of these teachers ranged from B teach + Dip Ed (34), Grad Dip (33), B. Ed (72), Double Degree (17), M. Teach (3), and others (49). The teachers came from middle primary and upper primary levels across different rural and urban schools within the state. Their teaching experiences varied - 5 years or below (24\%), six to ten years (16\%), 16 to 20 years (20\%), 21 to 30 years (27\%), and 31 to 41 years (13\%). They reported different practices in teaching. For example, regarding homework per week given to the students, 82 teachers reported giving less than 1 hour's homework, while the majority of the teachers (119) gave 1-2 hours of 
homework to their students, and the remaining six teachers reported giving up to 3-4 hours of homework per week.

\section{Materials}

Teachers were asked to respond to a survey. Background variables included gender, years of teaching experience, and academic and teacher qualifications. The survey was comprised of 22 items with three to five items measuring each of five factors (teacher self-concept, valuing of learning, conventional beliefs, student-centered teaching approach, and teacher-centered teaching approach). Scales and items were mostly developed from existing psychological measures but adapted to suit the current purpose. The scales and example items are shown in Appendix.

Teacher self-concept. Teacher self-concept was measured by five items adapted from the Marsh (1992) Self Description Questionnaire. The scale asked about the teachers' selfperception of how competent they were as a teacher.

Value. The Value scale was measured by four items. The scale asked about the extent to which the teachers value students' engagement in learning processes.

Beliefs. Measured by three items, this scale asked the extent to which the teachers held an "entity" belief that achievement is primarily dependent on ability and there is little one can do about it.

Student-centered approach. Student-centered teaching was measured by five items.

Teacher-centered approach was also measured by five items.

\section{Procedure}

Procedures approved by the university's ethics committee were followed. The printed survey was mailed to school teachers in 52 schools in both rural and urban regions, 26 of which were from urban areas and 26 were from rural areas. The teachers responded to the survey items in 
a random order on a 5 -point scale ( $1=$ false to $5=$ true). A total of 208 completed surveys were received (a return rate of about 22\%).

\section{Statistical Analyses}

The teachers' responses to the survey items were coded such that higher scores reflected more cohesion with the scales they belong to respectively. In preliminary analysis, we examined the Cronbach’s alpha estimate of internal consistency of each a priori scale. Then we conducted structural equation modeling (SEM) with the statistical package of Mplus, Version 6.0 (Muthén \& Muthén, 1998-2010). Using confirmatory factor analysis (CFA), we first started with a model testing the ability of the 22 items to form a single factor (Model 1). Second, a two-factor model was tested with the two predictors (self-concept and value) as a single factor, and the outcomes (beliefs, student-centered, and teacher-centered) as another factor (Model 2). Third, a five-factor model (Model 3) was tested (self-concept, value, beliefs, student-centered, and teacher-centered). We expected Model 3 to provide the best fit. Finally, based on Model 3, using SEM, we tested in Model 4 the paths from the two predictors (self-concept and value) to the three outcomes (beliefs, student-centered, and teacher-centered).

The procedures for conducting CFA and SEM have been described elsewhere (e.g., Jöreskog and Sörbom 2005; Muthén \& Muthén 1998-2010) and are not further detailed here. The goodness of fit of the CFA models was evaluated with an emphasis on the Tucker-Lewis index (TLI, also known as the non-normed fit index) as the primary goodness-of-fit index. However, the chi-square test statistic and root mean square error of approximation (RMSEA) and the comparative fit index (CFI), are also reported. In general, for an acceptable model fit, the values of TLI and CFI should be equal to or greater than .90 for an acceptable fit and .95 for an excellent fit to the data. For RMSEA, a value of .05 indicates a close fit, values near .08 indicate a fair fit (Browne \& Cudeck, 1993). In sum, support for an acceptable model requires (a) acceptable reliability for each scale (i.e., alpha=.70 or above), (b) an acceptable model fit 
(i.e., TLI and RNI=.90 or above and RMSEA<.08), (c) acceptable factor loadings ( $>.30$ ), and (d) acceptable correlations among the latent factors such that they would be distinguishable from each other $(r<.90)$.

\section{Results}

\section{Preliminary Analysis and CFA}

The alpha reliability of each scale, as presented at Appendix, was acceptable (alphas $=.82, .70, .78, .82$, and .78 for self-concept, value, ability belief, student-centered approach, and teacher-centered approach, respectively). All models resulted in proper solutions (Table 1). The CFA models (Models 1 to 3 ) tested the integrity of the factors. Model 1 testing the onefactor model (TLI=.61, CFI=.65, RMSEA=.11) and Model 2 testing the two-factor model did not fit the data well (TLI=.66, CFI =.69, RMSEA=.10). However, Model 3 testing the fivefactor model provided a reasonable fit (TLI=.94, CFI=.95, RMSEA=.04). The parameter estimates of Model 3 are given in Table 2, which also presents the means and standard deviations of the scales. The factor loadings were good (all factor loadings $>.50$ ). The factor correlations ranged from -.24 to .68 , indicating that the five factors were clearly distinguishable from each other. The correlation between self-concept and value was positive $(r=.46)$, which was logical and consistent with previous research showing a positive association between sense of competence and value (Wigfield \& Eccles, 2000). The two teaching approaches were positively correlated ( $r=.62)$, which was also reasonable. Value (advocating learning) was negatively correlated ( $r=-.24)$ with beliefs (a traditional assumption that student ability is a fixed attribute), indicating that a stronger advocate for student learning is associated with a weaker belief that some students are unable to learn. In sum, the factor loadings and the factor correlations supported the measurement model (Model 3). Based on the established factors in Model 3, we were able to test the relative influences of the two predictors (self-concept and value) on the three outcomes (beliefs, student-centered, and 
teacher centered) in a path model (Model 4). As Model 4 was equivalent to Model 3, they displayed the same model fit (Table 1) and the parameter estimates were identical, as presented in Table 2.

\section{Insert Tables 1 and 2 About Here}

\section{Path Model}

In the structural equation model (Model 4), the paths from two predictors to three outcome measures were examined. These paths are presented in Figure 1. From self-concept, the path to student-centered $(\beta=.48)$ and teacher-centered approaches $(\beta=.63)$ were both positive and significant $(p<.05)$, but the path to beliefs $(\beta=.10)$ was not significant. For value, two paths were significant: the path to beliefs was significantly negative $(\beta=-.29)$ whereas the path to student-centered approach was significantly positive $(\beta=.35)$. However, the path to teachercentered approach $(\beta=.12)$ was not statistically significant.

\section{Insert Figure 1 About Here}

\section{Discussion}

In the present study, we examined the relative predictions of two motivation variables on three outcomes. The purpose was to understand how teacher beliefs and teaching approaches are influenced by teachers' self-concept of competence and their valuing of learning. It is hoped that the findings will encourage education researchers and theorists to start delineating the potential links of teacher self-perception and value to teacher beliefs and teaching behaviors. The findings may therefore have important implications for educational researchers, school administrators, and teacher educators as they will provide useful directions to help teachers align their teaching methods in better ways to benefit teaching and learning outcomes.

Three hypotheses were tested. The analysis found support for hypothesis 1 ; that is, teacher self-concept was found to be strong in predicting both teaching approaches. The path from teacher self-concept to student-centered teaching approach was significantly positive 
$(\beta=.48)$ and so was the path to teacher-centered teaching approach $(\beta=.63$; Figure 1$)$. Hence teachers who had high competence beliefs about their teaching were likely to use both teaching approaches. This is consistent with Author (2012), who suggests that teachers use various teaching approaches in flexible ways depending on the classroom situation. Despite the ongoing debate regarding teacher-centered and student-centered teaching approaches (e.g., Åkerlind, 2007; Biggs, 2003; Cannon \& Newble, 2000; Honkimaki et al., 2004; Trigwell et al., 1999), it is interesting to note that the correlation between the two teaching approaches with this Australian sample was significantly positive ( $r=.62$; Table 2$)$. This suggests that the two teaching approaches may not be exclusive of each other as some researchers would assume.

Consistent with researchers who suggested a positive association between competence and value beliefs (e.g., Öztaş \& Dilmac, 2009; Wigfield \& Eccles, 2000), a significantly positive correlation was found between teacher self-concept and valuing of learning for the present sample ( $r=.46$; Table 2). This suggests that teachers' competence beliefs about teaching were related to their valuing of student learning. That is, teachers who were high in competence beliefs about their teaching were likely to advocate students’ learning. It is also interesting to note that for this sample, the teachers' competence beliefs $(M=3.20)$ and valuing of learning ( $M=4.38)$ were both high (Table 2), and neither of these perceptions tended to be associated with (rs were non-positive; Table 2), or reinforce the traditional assumption that student ability is a fixed attribute ( $\beta$ s were either nonsignificant or significantly negative; Figure 1).

Hypothesis 2 was also supported. That is, teachers who held a higher value for student learning tended to adopt a student-centered teaching approach $(\beta=.35)$ than a teacher-centered approach ( $\beta=.12$, nonsignificant). Hence in addition to the delivery of knowledge and enhanced student academic performance, students’ capabilities in critical thinking and problem solving are also critical. In this sense, teacher education should emphasize broader teacher 
developmental aims and goals. Through a clearer understanding of how teaching behaviors are related to teacher perceptions and motivation, we may identify the crucial constructs to which teacher education should attend. If student-centered teaching is believed to be the approach that would enable students to construct, own, and expand knowledge in a constructivist sense (Marshall, 1998; Mayer, 2009), then it would be logical to enhance teachers’ self-concept in teaching and valuing of students' learning. Our data showed that both of these constructs (self-concept and value) had significant impacts on the teachers' application of studentcentered approaches to teaching ( $\beta \mathrm{s}=.48$ and .35, respectively; Figure 1).

The significantly negative path from value to beliefs about student ability $(\beta \mathrm{s}=-.29)$ supported hypothesis 3 . That is, teachers who held higher value for student learning were more likely to refute the idea that student ability is stable and cannot be changed. Hence the more teachers believed in the value of promoting students' construction of knowledge, the less they believed in the biological constraints that limit students to excel. Conventional beliefs based on assumptions of biological limitations could have dire long-term consequences in teachers’ professional development. How such beliefs may have undesirable impact would need further explication, but they are clearly unrelated to either of the two prominent teaching approaches explored here ( $r$ s to both teaching approaches were close to zero; Table 2).

Regarding teaching approaches, the analysis showed that the two predictors were positively related to both teaching approaches when considered separately. The purpose of the path model (Figure 1) was to provide a more stringent explication of the relative strength of each predictor in predicting each outcome variable. The advantage of using this structural equation modeling approach is to be able to answer the research question of which predictor best predicts which outcome when there are two predictors and multiple outcomes to be tested simultaneously. The relative salience of the paths therefore adds to our understanding of which predictor needs more attention and provides a direction for teacher education so as to 
allocate resources more efficiently to focus on those most significant predictor variables. Structural equation modeling is therefore a powerful tool for this purpose.

Overall, self-concept was found to have relatively stronger influences on both teaching approaches (teacher-centered, $\beta=.63$; student-centered, $\beta=.48$ ). The results suggest that teachers who have good teaching self-concept may adopt both teacher-centered approaches and student-centered approaches depending upon the subject matter and the teaching goal. In other words, teachers' self-concept may be a good predictor of their teaching behaviors. In practical terms, teacher education should emphasize the development of teachers' self-concept. This can be done through a dual approach that emphasizes both the facilitation of effective teaching strategies/skills and the enhancement of competence beliefs in applying such strategies in real classroom contexts. This is echoed by Palmer (1998): "Good teaching cannot be reduced to techniques; good teaching comes from the identity and integrity of the teacher" (p. 10).

For teachers to shift from a traditional teacher-centered emphasis on knowledge delivery to a more constructivist perspective emphasizing a student-centered approach, it is important to reinforce teachers’ valuing of student learning. By strengthening teachers’ emphasis on how much is learned rather than how much is taught, teachers are more likely to adopt a student-centered approach that will logically lead to students' exploration and mastery of new knowledge. Hence to facilitate the increasingly advocated constructivist views of learning, our data show that teacher education should promote teachers' valuing of the learners’ learning rather than the teacher's teaching.

For self-concept, further research may also examine the relations of teacher self-concept to other variables from a twofold dimensional perspective (Author, 2011). That is, the differential influences of perceived competence in teaching and teachers' affect toward teaching may have differential influences on a range of teaching-related and learning-related 
variables. For example, Kim and Kim (2010) found, with a sample of Korean early childhood educators, that competence beliefs may not have direct bearing on psychological variables such as depression, but affective aspects of the self may be related to such variables. By examining the affective component of the self together with the competence component, we may be able to get better insight into directions for effective interventions to equip teachers for a more effective and more satisfying teaching career.

It is hoped that the findings will encourage educators and researchers to start delineating the potential links of teacher self-perception and value to teacher beliefs and teaching behaviors. The findings also have important implications for educational researchers, school administrators, and teacher educators as they suggest that teachers' self-concept and valuing of learning have a powerful relation with teaching approaches that foster student learning.

\section{Limitations}

This study has some limitations which can be addressed in future research. As students are the centre point of any teaching-learning process, elucidating students' viewpoints on different teaching methods could add an interesting aspect to the development of teaching theory and research. Our study has examined only two assumingly contrasting teaching approaches (which were found to be actually positive related). More research is needed to better understand a wider range of teaching methods, and find out which works best with which kinds of teachers and students and in which educational contexts. We also believe that many of the relations depicted in our model (e.g., outcomes and predictors) could be dynamic and reciprocal in nature. Hence the causal ordering of these variables should be explored in future research preferably via longitudinal research designs. Future studies may also explore processes through which teacher self-concepts may influence student thinking, beliefs, behavior, and achievement. Regarding the sample, although the gender proportion of $78 \%$ female (163 female and 45 male teachers) reflected our successful sampling strategy resulting 
in a ratio similar to that of the State, future research should attempt to obtain a larger sample so as to test gender differences and teacher characteristics from rural and urban regions. The low return rate (about 22\%) was also a limitation although it is not unusual with mailed surveys of teacher samples, especially from rural schools. Finally, one may suspect that at least some teachers would have provided "socially desirable” responses to the survey items. Nevertheless, the reasonable scores for the Beliefs factor ( $M=3.20$ which is above the midpoint on a 5-point scale) suggest that this may not be an issue with this teacher sample. Despite these limitations, the results presented here have demonstrated the importance of taking into account teachers' self and value perceptions in facilitating teaching in the shortterm and in their future career.

\section{Conclusion and Recommendations}

This is apparently one of the few studies to investigate the important influence of teacher selfconcept and valuing of learning on teacher beliefs and approaches. Overall, the results presented here demonstrate the importance of taking into account teachers' self-concepts and their value beliefs in order to facilitate student learning. These findings improve our understanding of the teaching process, and have important implications for teacher education programs. Given teacher self-concepts and valuing of learning significantly predict beliefs and teaching approaches, it is important to enhance preservice teachers' teaching self-concepts and values.

Our findings also showed that student-centered and teacher-centered approaches are highly correlated. As such, student-centered and teacher-centered learning environments should not be portrayed as opposing poles of one continuum; rather they are related. These results imply that preservice teachers should be empowered with the knowledge, skills, and attitudes about different teaching methods to create flexible teaching-learning environments to enhance student learning. After all, effective teachers in real-life classroom situations may 
choose to use a variety of pedagogical approaches to suit students' individual and different needs. Hence teachers will benefit from building their competence in a variety of approaches in their preservice teacher education programs.

The study also found that teachers’ perceptions not only influences the thinking process and decisions teachers make during their planning and interaction, it also has a significant impact on teaching behavior. This implies that it is important for teachers to evaluate their own teaching beliefs, apply their self-identified strengths through actual teaching behavior, and engage students in learning such that they perceive learning as enjoyable. It is therefore advisable for teacher education programs to include self-evaluation and reflection elements to enable teachers to engage in lifelong self-improvement. This can be facilitated by encouraging preservice teachers to develop a portfolio so that they can visualize their progress and use an evidence-based approach to further excel in their teaching. In essence, strategies to facilitate the development of teachers' self and value beliefs through the facilitation of various teaching approaches and evaluation of effectiveness should be an essential part of teacher education.

Overall the findings demonstrate that teachers' self-concept and values are important constructs that underpin quality teaching. Hence, these findings have significant implications for teacher education theory, research, and practice which are inextricably intertwined whereby weakness in any one area will undermine the others. Clearly, the results of this study add to teacher education theory in that self-concept and expectancy-value theories are salient for teachers and therefore are potentially potent theoretical perspectives for advancing theoretical understandings about teacher education. In practical terms, the results imply that no teacher educator is wasting her or his time in enhancing the teaching self-concepts of preservice or in-service teacher education students. Ideally in order to capitalize on the reciprocal relations that self-concept shares with performance (Author, 2008), enhancing teaching self- 
concept should be simultaneous with skills training. Furthermore, to account for the multidimensionality of the self-concept construct (Author, 2011) it would be useful for teacher educators to target the enhancement of teacher self-concept in specific self-concept domains (e.g., math, reading, science, physical education, creative arts self-concepts, etc.).

In summary, the results of this investigation imply that teacher education theory, research, and practice could be strengthened from a new program of research capitalizing upon self-concept theory and expectancy-value research. This perspective will enable us to explicate a deeper knowledge and understanding of the powerful influence of teachers' selfconcepts and values on student engagement and learning. 


\section{References}

Åkerlind, G. (2007). Constraints on academics’ potential for developing as a teacher. Studies in Higher Education, 32(1), 21-37.

Author (1997).

Author (1999).

Author (2008).

Author (2011).

Author (2012).

Biggs, J. (2003) Teaching for quality learning at university (2nd ed.). Buckingham, UK:

Society for Research in Higher Education \& Open University Press.

Browne, M.W., \& Cudeck, R. (1993). Alternative ways of assessing model fit. In K. A. Bollen \& J. S. Long (Eds.), Testing structural equation models (pp. 136-162). Newbury Park, CA: Sage.

Cannon, R., \& Newble, D. (2000). A guide to improving teaching methods: A handbook for teachers in university and colleges. London: Kogan Page.

Castling, A. (1996). Competence-based teaching and training. London: Macmillan Press Ltd.

Chen, S.M., \& Chang, Y.L. (2004). Beliefs and practices of kindergarten teachers. Journal of Pingtung Teachers College, 21, 1-35.

Chen, J.Y., Chang, H.P., Yang, H.F., \& Cheng, Y.T. (2006). A school-based collaborative professional development project: The investigation of an experienced teacher's teaching belief and teaching research. Science Education Monthly, 294, 2-14.

Corey, G., Corey, M.S., \& Callahan, P. (2003). Issues and ethics in the helping professions (6th ed.). Pacific Grove, CA: Brooks/Cole.

Cuban, L. (1983). How did teachers teach, 1890-1980. Theory Into Practice, 22(3), 160-165. 
Devos, C., Dupriez, V., \& Paquay, L. (2012). Does the social working environment predict beginning teachers’ self-efficacy and feelings of depression? Teaching and Teacher Education, 28(2), 206-217.

Doolittle, P.E., \& Camp, W.G. (1999). Constructivism: The career and technical education perspective. Journal of Vocational and Technical Education, 16(1), 23-46.

Dweck, C.S., Chiu, C., \& Hong, Y. (1995). Implicit theories and their role in judgments and reactions: A world from two perspectives. Psychological Inquiry, 6, 267-285.

Erdley, C.A., \& Dweck, C.S. (1993). Children’s implicit personality theories as predictors of their social judgments. Child Development, 64, 863-878.

Gow, L., \& Kember, D. (1993). Conceptions of teaching and their relationship to student learning. British Journal of Education Psychology, 63, 20-22.

Heslin, P.A., Latham, G.P., \& Vande Walle, D. (2005). The effect of implicit person theory on performance appraisals. Journal of Applied Psychology, 90, 842-856.

Jöreskog, K.G., \& Sörbom, D. (2005). LISREL 8.72: Structural Equation Modeling with SIMPLIS command language. Chicago: Scientific Software International.

Hattie, J.A.C. (2008). Visible learning: A synthesis of meta-analyses relating to achievement. New York: Routledge.

Ho, A., Watkins, D., \& Kelly, M. (2001). The conceptual change approach to improving teaching and learning: An evaluation of a Hong Kong staff development programme. Higher Education, 42(2), 143-169.

Hofstede, G. (1980). Culture's consequences: International differences in work related values. Beverly Hills, CA: Sage.

Honkimaki, S., Tynjala, P., \& Valkonen, S. (2004) University students’ study orientations, learning experiences and study success in innovative courses. Studies in Higher Education, 29(4), 431-449. 
Hsiao, H., \& Yang, S. (2010). The study of teaching beliefs reflected on teaching behavior: Focusing on elementary school teachers. The International Journal of Learning, 17(9), 299-309.

Huang, J.C. (2006). A study of novice teachers' teaching beliefs and their performances in teaching: A primary survey for kindergarten teachers. Educational Review, 27, 123-144.

Kim, Y.H., \& Kim, Y.E. (2010). Korean early childhood educators' multi-dimensional teacher self-efficacy and ECE center climate and depression severity in teachers as contributing factors. Teaching and Teacher Education, 26, 1117-1123.

Klassen, R.M., \& Chiu, M.M. (2010). Effects of teachers’ self-efficacy and job satisfaction: Teacher gender, years of experience, and job stress. Journal of Educational Psychology, 102, 741-756.

Lee, M-H., \& Tsai, C-C. (2010). Exploring teachers’ perceived self efficacy and technological pedagogical content knowledge with respect to educational use of the world wide web. Instructional Science, 38, 1-21.

Lim, C., \& Torr, J. (2007). Singaporean early childhood teachers’ beliefs about literacy development in a multilingual context. Asia-Pacific Journal of Teacher Education, 35(4), 409-434.

Loughran, J. (2006). Developing a pedagogy of teacher education: Understanding teaching and learning about teaching. London: Routledge.

Marsh, H.W. (1992). Self Description Questionnaire (SDQ) II. Australia: University of Western Sydney.

Marshall, H.H. (1998). Teaching educational psychology: Learner-centered constructivist perspectives. In N. M. Lambert \& B. L. McCombs (Eds.), How students learn: Reforming schools through learner-centered education (pp. 449-461). Washington, DC: American Psychological Association. 
Mayer, R.E. (2009). Constructivism as a theory of learning versus constructivism as a prescription for instruction. In S. Tobias \& T. M. Duffy (Eds.), Constructivist instruction: Success or failure? (pp. 184-200). New York: Routledge.

Muthén, L.K., \& Muthén, B.O. (1998 -2010). Mplus user's guide (5 ${ }^{\text {th }}$ ed.). Los Angeles, CA: Muthén and Muthén.

Öztaş, F., \& Dilmac, B. (2009). Value judgments and perceived self-efficacy of biology teacher candidates. Social Behavior and Personality, 37(3), 329-334.

Palmer, P. (1998). The courage to teach: Exploring the inner landscape of a teacher's life. San Francisco, CA: Jossey-Bass.

Ramsden, P. (1992). Learning to teach in higher education. London: Routledge.

Rattan, A., Good, C, \& Dweck, C.S. (2012). “It’s OK-Not everyone can be good at math”: Instructors with an entity theory comfort (and demotivate) students. Journal of Experimental Social Psychology, 48, 731-737

Roche, L.A., \& Marsh, H.W. (2000). Multiple dimensions of university teacher self-concept: Construct validation and the influence of students' evaluations of teaching. Instructional Science, 28, 439-468.

Sang, G., Valcke, M., van Braak, J., \& Tondeur, J. (2009). Investigating teachers’ educational beliefs in Chinese primary schools: Socioeconomic and geographical perspectives. Asia-Pacific Journal of Teacher Education, 37 (4), 363-377.

Saunders, W., \& Goldenberg, C. (1996). Four primary teachers work to define constructivism and teacher-directed learning: Implications for teacher assessment. The Elementary School Journal, 97(2), 139-161.

Schuh. K.L. (2004). Learner-centered principles in teacher-centered practices? Teaching and Teacher Education, 20, 833-846. 
Schwartz, S.H., \& Bilsky, W. (1987). Toward a psychological structure of human values. Journal of Personality and Social Psychology, 53, 550-562.

Stuart, C., \& Thurlow, D. (2000). Making it their own: Preservice teachers' experiences, beliefs, and classroom practices. Journal of Teacher Education, 51(2), 113-121.

Swan, M. (2007). Designing and using research instruments to describe the beliefs and practices of mathematics teachers. Research in Education, 75, 58-70.

Tschannen-Moran, M., \& Woolfolk Hoy, A. (2001). Teacher efficacy: capturing an elusive construct. Teaching and Teacher Education, 17, 783-805.

Trigwell, K., Prosser, M., \& Waterhouse, F. (1999). Relations between teachers’ approaches to teaching and students' approaches to learning. Higher Education, 37, 57-70.

Wang, G.J. (2000). Exploring the relationship between teaching beliefs and teaching practices of teachers. Educational Research \& Information, 8(2), 84-98

Wigfield, A., \& Eccles, J.S. (2000). Expectancy-value theory of achievement motivation. Contemporary Educational Psychology, 25(1), 68-81.

Yeung, A.S., Taylor, P.G., \& McWilliam, E.L. (2012): Inventory of pedagogy and practice: Confirmatory factor analysis of multiple facets of teaching. International Journal of Research \& Method in Education. doi:10.1080/1743727X.2012.696243

Zeng, S.L.K. (2008). Relationships of teaching beliefs and effective teaching performances for preschool physical education teachers. Physical Education Journal, 41(2), 55-68. 


\section{Appendix}

\begin{tabular}{|c|c|}
\hline Variables & Alpha \\
\hline Teacher Self-Concept & .82 \\
\hline - I am good at teaching most subjects that I teach & \\
\hline - I am confident that if students misbehave I can manage the situation & \\
\hline - I can teach numeracy skills well & \\
\hline $\begin{array}{l}\text { - I am confident that I can maintain a calm learning environment through engaging } \\
\text { students in worthwhile learning }\end{array}$ & \\
\hline - I can teach literacy skills well & \\
\hline
\end{tabular}

\begin{tabular}{|c|c|}
\hline Values & .70 \\
\hline - I consider student understanding of assessment strategies to be important & \\
\hline $\begin{array}{l}\text { - I consider the school support for communication about student learning between home } \\
\text { and school to be very important for }\end{array}$ & \\
\hline - I consider parents' understanding of assessment information to be important & \\
\hline $\begin{array}{l}\text { - I consider students reflecting on their learning and engaging in self-assessment to be } \\
\text { important }\end{array}$ & \\
\hline
\end{tabular}

\begin{tabular}{|l|c|}
\hline Beliefs & .78 \\
\hline $\begin{array}{l}\text { When given challenging tasks students with high prior achievement are more likely to } \\
\text { do well than low achieving students }\end{array}$ & \\
\hline $\begin{array}{l}\text { Students with low prior achievement are less likely to do well if given challenging } \\
\text { tasks }\end{array}$ & \\
\hline - Challenging tasks are most effective for students with high prior achievement & \\
\hline
\end{tabular}

\begin{tabular}{|c|c|}
\hline Student-centered approach & .82 \\
\hline - I encourage my students to take risks in their learning & \\
\hline - I provide opportunities for my students to analyze and synthesize information & \\
\hline - I encourage my students to consider knowledge from different perspectives & \\
\hline $\begin{array}{l}\text { - I ask my students questions to make them think and to engage them in higher order } \\
\text { thinking }\end{array}$ & \\
\hline - I get my students to think deeply about important ideas & \\
\hline
\end{tabular}

\begin{tabular}{|c|c|}
\hline Teacher-centered approach & .78 \\
\hline - I show my students what they need to do to achieve well in their school work & \\
\hline - I explain to my students the best strategy to complete any given task & \\
\hline - I show my students how to do more difficult tasks & \\
\hline - I explain all aspects of the tasks students have to do clearly from the start & \\
\hline - I make sure my students understand what they have to do & \\
\hline
\end{tabular}

Note: A 5-point scale was used (1=false to $5=$ true). 
Table 1. Goodness of Fit

Model

$\chi^{2} \quad \underline{d f} \quad \underline{\text { TLI }} \underline{\text { CFI }}$ RMSEA

1. 1 Factor

729.63

$\begin{array}{llll}209 & .61 & .65 & .11\end{array}$

2. 2 Factors

$\begin{array}{lllll}660.36 & 208 & .66 & .69 & .10\end{array}$

3. 5 Factors

270.52

$\begin{array}{llll}199 & .94 & .95 & .04\end{array}$

4. Path Model

270.52

199

$.94 \quad .95 \quad .04$

Note: $N=208$. 
Table 2. Model 3

$\begin{array}{rllllll} & \text { Self-concept } & \text { Value } & \text { Beliefs } & \begin{array}{l}\text { Student- } \\ \text { centered }\end{array} & \begin{array}{l}\text { Teacher- } \\ \text { centered }\end{array} & \text { Uniqueness } \\ \text { Mean } & 4.48 & 4.38 & 3.20 & 4.22 & 4.54 \\ \text { SD } & 0.45 & 0.50 & 0.82 & 0.56 & 0.44\end{array}$

Factor Loadings

Self-concept1

SC-concept2

$.72 *$

SC-concept3

$.69 *$

SC-concept4

$.67 *$

$.59 *$

SC-concept5

$.77 *$

value1

value2

value3

value4

beliefs1

beliefs2

beliefs3

student-centered1

student-centered2

student-centered3

student-centered4

student-centered5

teacher-centered1

teacher-centered2

teacher-centered3

teacher-centered4

teacher-centered5
4.38
0.50

0.82

0.56

$.48^{*}$

$.53 *$

$.56^{*}$

$.65^{*}$

$.41 *$

$.69 *$

$.69 *$

$.57 *$

$.63 *$

$.53 *$

$.14 *$

$.63 *$

$.70 *$

$.46 *$

$.48 *$

$.51^{*}$

$.45 *$

$.74 *$

$.62 *$

$.60 *$

$.61 *$

$.63 *$

$.71 * \quad .50 *$

$.62 * \quad .62 *$

$.72 *$

$.49 *$

\section{Factor Correlations}

\begin{tabular}{llll} 
value & $.46^{*}$ & & \\
beliefs & -.03 & $-.24^{*}$ & \\
student-centered & $.63^{*}$ & $.56^{*}$ & -.01 \\
teacher-centered & $.68^{*}$ & $.41^{*}$ & .02 \\
\hline
\end{tabular}

$.62 *$

Note: $N=208 .{ }^{*} p<.05$. 
Figure 1. Path model

Note: ${ }^{*} p<.05$.

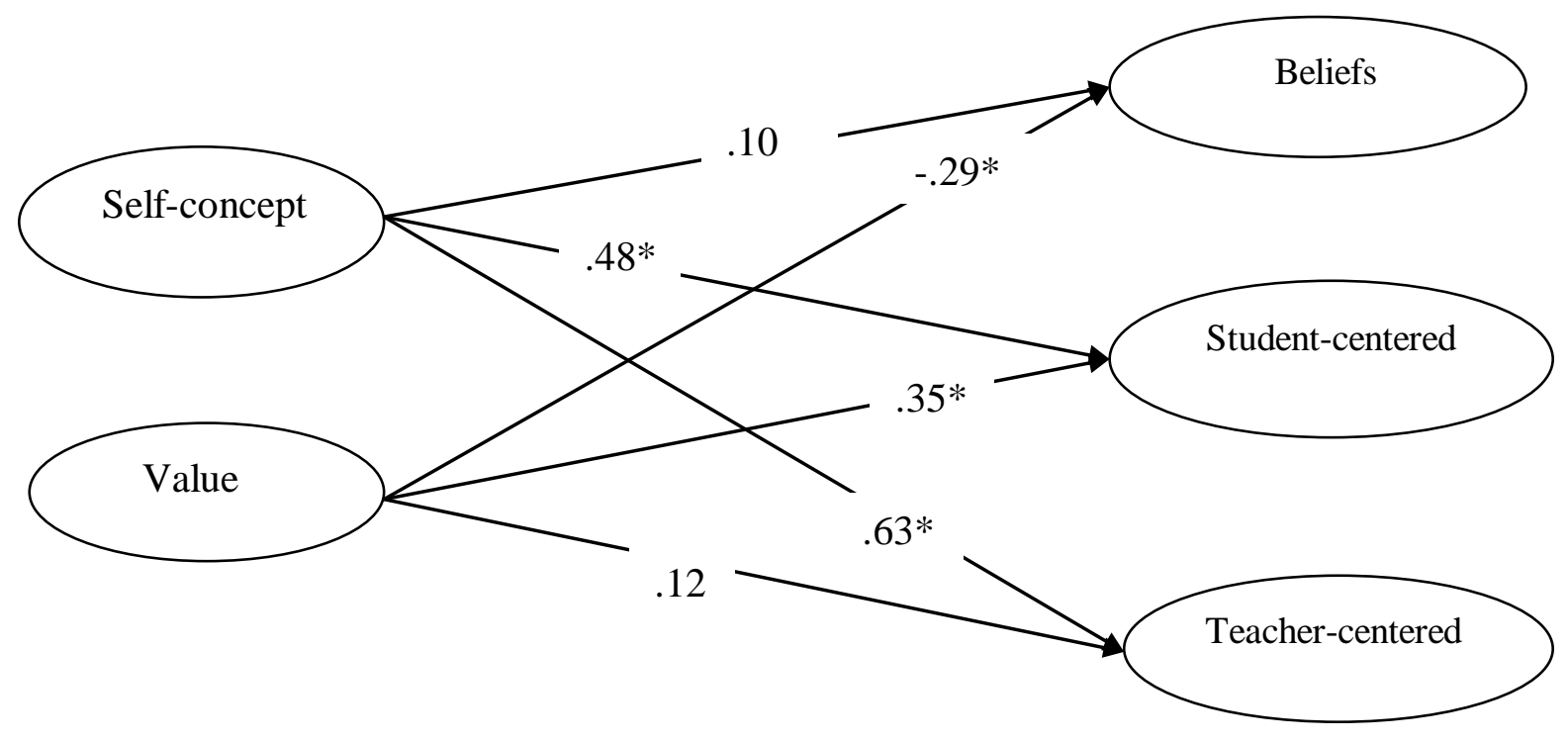

